STUDI

FRANCESI

\section{Studi Francesi}

Rivista quadrimestrale fondata da Franco Simone

185 (LXII | II) | 2018

OCTAVE MIRBEAU: UNE CONSCIENCE AU TOURNANT

DU SIEECLE - sous la direction de Ida Merello

\title{
FRANÇOISE FERY-HUE, “L'An des sept dames”: une cuvre tardive de Philippe Bouton
}

\section{Maria Colombo Timelli}

\section{(2) OpenEdition \\ Journals}

Édition électronique

URL : http://journals.openedition.org/studifrancesi/13407

DOI : $10.4000 /$ studifrancesi. 13407

ISSN : 2421-5856

Éditeur

Rosenberg \& Sellier

Édition imprimée

Date de publication : 1 août 2018

Pagination : 309

ISSN : 0039-2944

\section{Référence électronique}

Maria Colombo Timelli, « FRAnçoIse FERY-HUE, "L'An des sept dames": une œuvre tardive de Philippe Bouton », Studi Francesi [En ligne], 185 (LXII | II) | 2018, mis en ligne le 01 août 2018, consulté le 06 janvier 2021. URL : http://journals.openedition.org/studifrancesi/13407; DOI : https://doi.org/ 10.4000/studifrancesi. 13407

Ce document a été généré automatiquement le 6 janvier 2021.

\section{(c)}

Studi Francesi è distribuita con Licenza Creative Commons Attribuzione - Non commerciale - Non opere derivate 4.0 Internazionale. 


\title{
FRANÇOISE FERY-HUE, “L'An des sept dames": une œuvre tardive de Philippe Bouton
}

\author{
Maria Colombo Timelli
}

\section{RÉFÉRENCE}

FRANÇOISE FERY-HUE, "L'An des sept dames": une ceuvre tardive de Philippe Bouton, «Quaderni di filologia e lingue romanze» 31, 2016, pp. 7-30.

1 Ce très bel article présente un poème peu connu composé en 1503 dans les Pays-Bas bourguignons: dans 365 huitains, un auteur anonyme célèbre les mérites de sept dames en ayant recours «à toutes les ressources de son imagination» (p. 8). Transmis par un imprimé (Anvers, Thierry Martens, 1504) et par un manuscrit de luxe copié sur celui-ci en 1515-1517, l'An des sept dames est remarquablement analysé par F.F.-H., qui prend en compte tant la transmission du texte, que l'histoire des deux seuls exemplaires connus de l'édition anversoise, pour en arriver à prouver - de façon tout à fait convaincante l'attribution à Philippe Bouton, courtisan des ducs de Bourgogne et auteur de pièces de circonstance et d'œuvres moralisantes, ainsi que de poèmes «fort lestes» (p. 16). 